\title{
The costs and risks of coping with drought: livelihood impacts and farmers' responses in Burkina Faso
}

\author{
Carla Roncoli $^{1, *}$, Keith Ingram ${ }^{1}$, Paul Kirshen ${ }^{2}$ \\ ${ }^{1}$ Department of Crop and Soil Sciences, The University of Georgia, 1109 Experiment Street, Griffin, \\ Georgia 30223-1797, USA \\ ${ }^{2}$ Civil and Environmental Engineering Department and Fletcher School of Law and Policy, Anderson Hall, Tufts University, \\ Boston, Massachusetts 02155, USA
}

\begin{abstract}
This paper analyzes the responses enacted by families of the Central Plateau in Burkina Faso during the year that followed a severe drought in 1997. We illustrate the agro-ecological and socio-economic contexts that shape livelihood options and constraints in an area characterized by high levels of climatic risk and low natural resource endowment. A description of farmers' perceptions and official accounts identifies key criteria whereby farmers formulate evaluations and predictions of a season. We document how food procurement and management practices are shaped by household resource access profiles and livelihood portfolios. Livelihood diversification, encompassing migration, non-farm work and social support networks, in addition to livestock production, is shown to be a critical dimension of adaptation. Livelihood and production adjustments entail costs and risks for most, but also gains for those who have the resources needed to take advantage of distress sales and high prices of agricultural commodities. Household livelihood and risk management increasingly hinge on efforts by household members who traditionally have had marginal access to resources, especially women. The research points to the need for closer integration of drought preparedness efforts, farmers' understanding of climate-crop interactions and interventions that bolster the capacity of resource-limited households to respond. Affordable grain, locally adapted seed varieties, labor saving technology and flexible credit are among the most needed inputs.
\end{abstract}

KEY WORDS: Rainfed agriculture - Burkina Faso · Coping strategies · Food security · Household livelihood $\cdot$ Drought $\cdot$ Climate variability $\cdot$ Risk management

Resale or republication not permitted without written consent of the publisher

\section{INTRODUCTION}

In 1997 rural families of Burkina Faso experienced one of the driest years in decades, which resulted in widespread crop losses and food deficits. Over 250000 people faced high levels of food insecurity as a result of this drought. ${ }^{1}$ This paper analyzes the responses enacted by families of the Central Plateau during the year that followed the drought. In particular, we examine how food procurement strategies, production adjustments and livelihood outcomes were shaped by household resource access profiles and livelihood port-

*E-mail: croncoli@gaes.griffin.peachnet.edu folios (Blaikie et al. 1994, Scoones 1998). The case in question represents the livelihood and production dilemmas faced by farming households in areas characterized by high levels of climatic risk and low natural resource endowment, where absolute income loss may be lower than in better endowed areas but the human

\footnotetext{
${ }^{1}$ http://www.fews.org/bf980262/sh980626.html\#bf. In this paper we use the term 'drought' to translate the common French term sécheresse used by educated local people without entertaining the debate of its meteorological, hydrological or agronomic definitions. The Moré term waré refers to both a dry year and a dry period during the rainy season, including failure of expected rains event, such as planting rains
} 
costs may be higher because many households operate near the margins of subsistence (Scoones 1998).

The identification of factors that shape vulnerability and the documentation of the type, range and sequence of coping strategies can inform policies and programs to reduce exposure to risk, to assess need and prioritize interventions, to alleviate the impacts of stress and to enable those affected to recover in timely fashion (Corbett 1988, Campbell 1990, Downing 1990, Adams et al. 1998, Benson 1998). But some have disputed the concept of 'coping' as being too static or too simplistic, not accounting for the dynamic and diverse nature of rural livelihoods. They warn against the danger of evaluating risk and need on the basis of decontextualized observation of household behavior (Lambert 1994, Davis 1996). Such behavior, in fact, may indicate different conditions in different places or times. Fungible resources may be alternatively allocated to consumption, production or reproduction (Downing 1990, Lambert 1994). For example, animal sales may be a stage in resource accumulation; that is, animals bought with revenue from crop sales may be sold to hire labor for farm operations or as starting capital for dry season enterprises. Grain may be bought for food, but also used to sow fields, entertain labor parties, host funeral celebrations or brew beer for sale.

Recent reviews of coping strategy research have pointed to the need for contextualized analysis of variation between and within groups in the ability to withstand and recover from food crises (Campbell 1990, Adams et al. 1998, Hussein \& Nelson 1998). Short-term survival may undermine long-term viability or may weigh unequally upon social categories, economic sectors and natural resources. At times of shortage, women may endure the costs of others' survival, depriving themselves in order to feed husbands and children or using up their petty trade capital to buy food (Whitehead 1981, Cutler 1984, Jiggins 1986, Corbett 1988, Davis 1993).

Research on household coping strategies stemming from the major West African droughts of the mid-1970s and mid-1980s documents the predicaments of household decision making at times of food crisis, when scarce resources must be allocated to the competing, at times contradictory, demands of production and reproduction (Adams et al. 1998). Households may elect to forego reproductive needs in order to hold on to their productive viability by reducing food consumption and social obligations, or they may be forced to deplete their productive assets and buffer stocks (Devereux 1993, Lambert 1994, Fafchamps et al. 1998). Resourcelimited farmers may choose to grow lower yielding drought-resistant crops and varieties, foregoing greater returns to land and labor (Dercon 1996). An appreciation of these trade-offs should inform policy approaches aimed at bolstering the coping capacity of rural livelihoods to avoid reinforcing the marginalization of certain groups or perpetuating unproductive or unsustainable resource use (Adams et al. 1998).

An analysis of the differing abilities of households to absorb and recover from climate shocks has been recently highlighted as key to a definition of sustainability (Davis 1996, Scoones 1998). Evidence from West Africa, and especially recent research carried out within the sustainable livelihood framework of analysis, points to diversification as a crucial mechanism whereby households cope with high levels of income and production uncertainty (Painter et al. 1994, Davis 1996, Ellis 1998, Brock 1999). Agricultural diversification allows farming households to diffuse risks by mixing crops and varieties in the same field, by staggering planting and scattering crops in different soils, fields and locations, and by enacting water conservation measures (Sanders et al. 1990, Carter 1997). Economic diversification, or the ability to spread risk over space and sectors, broadens households' access to resources and livelihood options among activities with different sensitivities to climatic shock. Inter-regional and ruralurban linkages and non-farm income sources are key factors that farming households can draw upon in coping with climate shocks (Reardon et al. 1988, Reardon \& Matlon 1989, Reardon \& Taylor 1996). Finally, social diversification and involvement and investment in social networks mediate access to key resources and provide support during time of crisis, especially for the rural poor (Bratton 1987, Berry 1989, Carter 1997).

The long-term implications of livelihood diversification and other risk management strategies for sustainable development need to be assessed in light of their context specificity and their differentiated nature (Hussein \& Nelson 1998). The case study presented here illustrates the diversified matrix of responses enacted by differently endowed households and by differently positioned household members, as well as the tensions and negotiations they set in motion. It also bridges the immediate aftermath of the drought, in which households strategize to cope with food insecurity, and the longer-term reverberations of climate shock that stem from the impacts such strategies have on agricultural practices during the subsequent rainy season. Finally, we suggest how scientific information, policy approaches and development interventions can contribute to a better integration of equity and sustainability concerns into drought preparedness efforts.

\section{CONTEXTS OF COPING}

The findings presented here emerged in the course of ethnographic research undertaken as part of the 


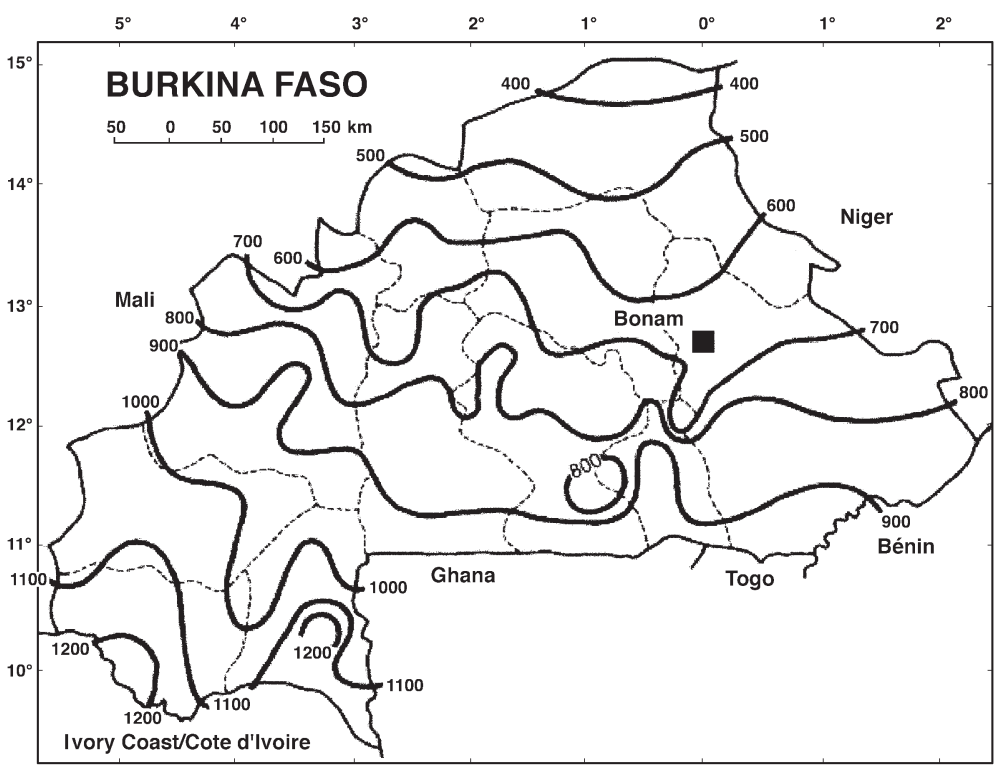

Fig. 1. Map of Burkina Faso

The Central Plateau research site is the village of Bonam (2800 inhabitants), located about $100 \mathrm{~km}$ northeast of Ouagadougou, the capital of Burkina Faso, and $20 \mathrm{~km}$ from Boulsa, the administrative center of the Namentenga Province. A 1997 UNDP report placed Namentenga Province among the most economically and ecologically disadvantaged in the country (PNUD 1997). This marginality can be attributed to a combination of factors, including scarce and irregular rainfall, infertile and degraded soils, underdeveloped transportation infrastructure and a dearth of non-farm employment opportunities.

Rain is life in Bonam, where rainfed farming is the main source of livelihood for local Mossi households and scattered hamlets of pastoralist Fulani who have settled in the area. As in the rest of the Sudan-Sahel region, rain falls during a

Climate Forecasting and Agricultural Resources (C FAR) project, a multidisciplinary initiative funded by the US National Oceanic Atmospheric Administration's Office of Global Programs and jointly implemented by the University of Georgia and Tufts University between 1997 and 2000. This project aims for a better understanding of how both regional and national institutions and farming households of the Sudan-Sahel region of West Africa can use seasonal precipitation forecasts to improve resource productivity in farming systems. The ethnographic component of the project explored the role of rainfall in productive and livelihood strategies in 3 different agroecological sites with different climatic profiles. This paper focuses on research carried out in the Central Plateau of Burkina Faso (Fig. 1).

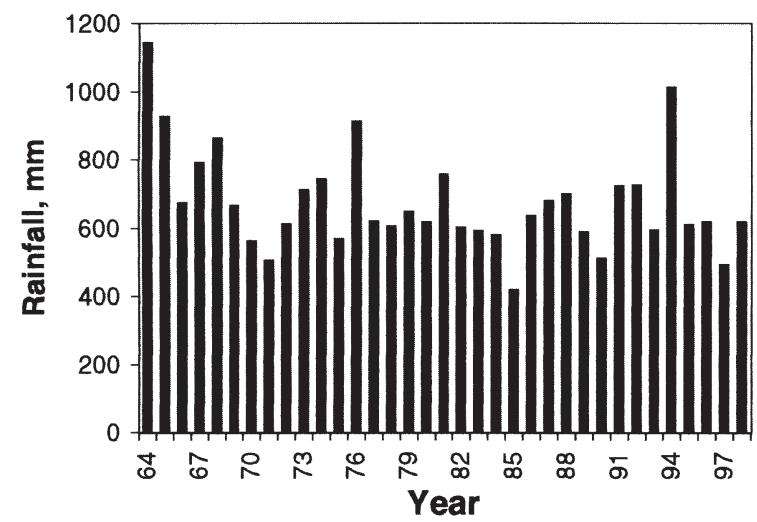

Fig. 2. Yearly rainfall at Boulsa, Burkina Faso, 1964-1998. Data from Direction Provinciale d'Agriculture single season from May to October, with $90 \%$ of the total during July to September. Rainfall is characterized by a high degree of spatial and temporal variability (Fig. 2). The long-term (1964 to 1998) mean annual rainfall is $674 \mathrm{~mm}$, but even within a few years, it can register values close to the long-term maximum and minimum and average. For instance, Boulsa received $1050 \mathrm{~mm}$ of rainfall in 1994, but only $491 \mathrm{~mm}$ in 1997, the second lowest rainfall in $35 \mathrm{yr}$, and $617 \mathrm{~mm}$ in 1998, which is close to the long-term average. ${ }^{2}$

During normal years, the farming season begins with the first rains in May, when farmers begin planting valley bottom fields with flood-resistant varieties of sorghum and rainfed rice. Farmers then proceed to plant a constellation of fields in various locations with drought-resistant varieties of sorghum and millet, intercropped with cowpea. Maize is also grown in relatively fertile areas of compound farms and small plots of peanut, and Bambara nuts are planted by women in marginal soils. The construction of a dam in Bonam in 1997 by a United Nations-funded project has enabled some farmers to begin growing dry season irrigated crops for both consumption and marketing.

Besides agriculture, livestock, trade and crafts provide the main sources of cash income available locally. Labor migration to Côte d'Ivoire, which began under French colonial administration, continues to attract young men and plays a crucial role in local livelihoods, but more recently irrigated schemes in southern Burkina Faso have also been attracting migrants. Most

${ }^{2}$ Data provided by the Direction Provinciale de l'Agriculture of Namentenga 
households have relatives working as farm laborers or sharecroppers in Côte d'Ivoire, with brothers often taking turns to migrate or to stay at home. Women sell sauce ingredients or cooked foods as their main income-generating activity. Non-farm income-generating activities are mostly carried out during the dry season, when people have more time and money and there is greater demand for goods in local markets.

Bonam is situated on what used to be an important road linking the Sahelian livestock production areas with important market town of Puytenga, which attracts traders from neighboring countries. But the road is now in disrepair and Bonam remains in a marginal position with respect to market and transportation networks. The village hosts a market that follows a $3 \mathrm{~d}$ cycle, serving a network of smaller villages in the surrounding areas, as well as some traders, who buy small surpluses of grain and other farm products after the harvest to sell to wholesalers in Boulsa and Puytenga. Several non-governmental organizations (NGOs) have been active in the area with various interventions, including drilling bore-holes, health education, literacy classes, micro-credit for women, distribution of transportation and plowing equipment, soil and water conservation, and food aid.

We began working in the area in January and February 1998, shortly after the 1997 harvest, which occurred between October and December and was an unmitigated disaster for most crops. Low yields meant a much greater dependence on grain imports and market purchases for an area that in good years exports modest surpluses. We returned in June and July 1998, when farmers were working hard at planting their new crops, grain was scarce and costly on the market, and the hunger season was reaching its peak. As they entered the new farming season, local families were stretched to the limits of their resources and yet faced several months before harvesting the new crops. Fortunately, rains were adequate and the new harvest brought much needed relief to the area. Our third study period was in January 1999, just as families were beginning to recover and, in some cases, reconstitute their depleted assets.

The research design combined a variety of qualitative and quantitative methods of data collection. To gather background information and enable the community to become acquainted with our presence, we first carried out focus groups with different social groups (farmers, herders, women) and open-ended interviews with resource persons. Then we conducted 3 rounds of a household survey on production and livelihood strategies in January and June 1998 and January 1999, as well as group semi-structured interviews with sub-samples of selected households on agricultural decision-making and farm histories. We
Table 1. Average per (adult) capita wealth of 21 households of the Central Plateau, Burkina Faso. CFA Fr: Communauté Financière Africaine francs

\begin{tabular}{|lcc|}
\hline & $\begin{array}{c}\text { Higher rank } \\
(\mathrm{n}=8)\end{array}$ & $\begin{array}{c}\text { Lower rank } \\
(\mathrm{n}=13)\end{array}$ \\
\hline $\begin{array}{l}\text { Average per household } \\
\text { (CFA Fr) } \\
\% \text { of sample average }\end{array}$ & 131648 & 33625 \\
\hline
\end{tabular}

also developed case studies of extra-sample households, representing specific livelihood portfolios and trajectories, such as the case of the wealthy farmertrader we will refer to in the course of this paper. The survey sample comprised 18 randomly selected compounds, $10 \%$ of all compounds in Bonam. Because a compound may include more than 1 household (defined as those who farm and eat together from a common granary) the original sample comprised 25 households, led by either the compound head or 1 of his brothers or sons. After the 1997 drought, 4 households migrated to Côte d'Ivoire and southern Burkina Faso, leaving 21 households with a complete data set. This sample size allowed for frequent and personalized interaction, enabling us to collect reliable data and to contextualize our interpretations.

Sample households were ranked according to wealth per (adult) capita, by calculating the value of animals owned and other liquid assets, such as plows, donkey carts, mopeds, bicycles and radio-cassette players, at the average selling prices obtained in $1998 .^{3}$ Wealth endowments for the 2 resulting strata, both above and below the sample average wealth, were skewed. Higher and lower ranking households had an average wealth per capita that is respectively twice and half that of the sample average (Table 1$)^{4}$

\footnotetext{
${ }^{3}$ Wealth is an imprecise measure because (1) ownership is embedded in kinship relationships in ways that may span individuals or households; (2) wealth is a dynamic variable with frequent turnover and transactions, especially during the dry season, when animals are sold or slaughtered for religious and social celebrations; and (3) possessions are only one aspect of the complex mix of material, social and cultural factors that affect household prestige and position in the local social organization and household access to key resources

${ }^{4}$ We also ranked households with the help of 2 research assistants, and 3 local informants ranked households by using local indicators of wealth and well-being. The most salient differentiating criteria referred to material possessions, especially animals; labor force, especially male; and livelihood security, especially food availability. The 2 resulting categories translate into something like 'the haves' (sen taré) and 'the have nots' (sen pataré) and included the same set of households as those produced on the basis of wealth per capita
} 


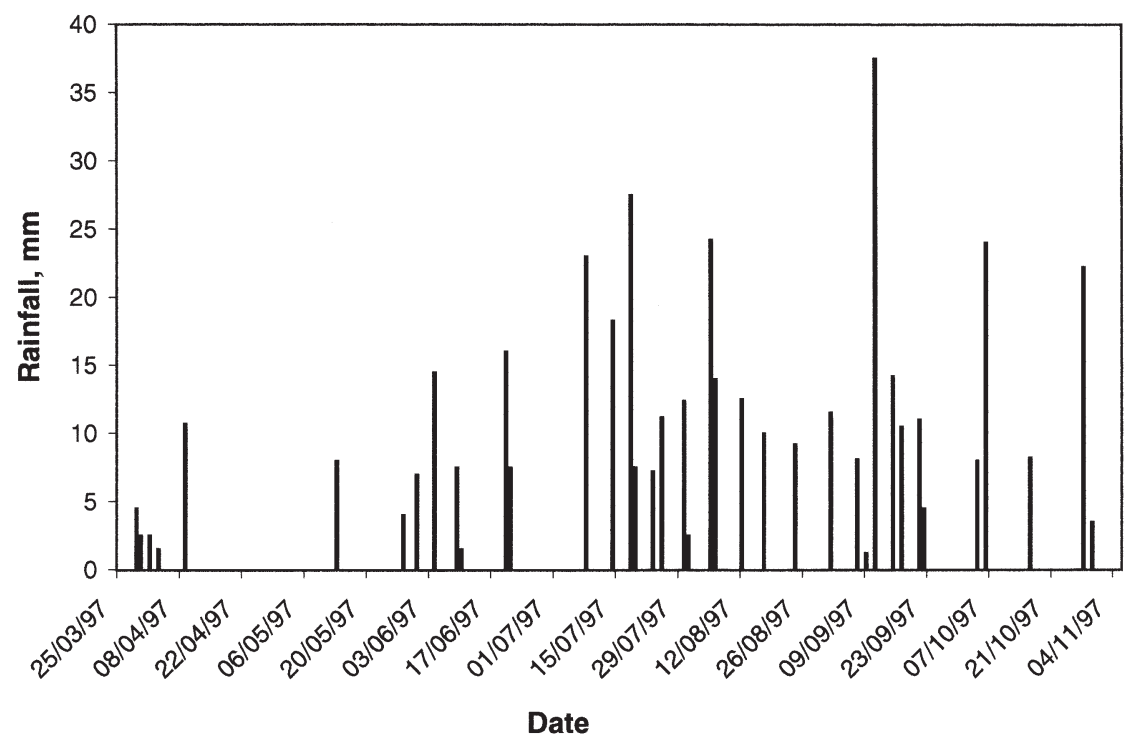

Fig. 3. Daily rainfall at Boulsa, Burkina Faso, 1997

Notably, assets made up a greater proportion of wealth owned by higher ranking households $(75 \%)$ than wealth owned by lower ranking households $(57 \%)$. This may have been due to their ownership of expensive items, such as motorcycles, but underreporting of cattle they had entrusted to Fulani caretakers may also have been a factor. Motorcycles are a status symbol as well as an economic advantage, as they enable their owners to travel and transport things between markets and to have access to services and information in town. Six of the 8 higher ranking households owned plows and donkey carts, and the two that did not own them had access to them within their compounds. Only 1 lower ranking household owned a plow and donkey cart, notably the most affluent among them, which is also related to the chief. Ownership of plows and other assets partly reflects the better access of higher ranking households to credit programs. Credit access is often through personal and political connections. These technologies enable households to expand and diversify their land holdings and complete farming operations more rapidly, an advantage that is vital in coping with a shortened rainy season. ${ }^{5}$ One farmer evaluated the value of plows as having 2 additional men in the household.

\footnotetext{
${ }^{5}$ The importance of timely planting and scarcity of plows, which are owned by only one-third of households, means that renting plows is uncommon, unlike elsewhere in the country (Hansen \& Reenberg 1998). Households that do not own plows most often opt for planting by hand rather than waiting for plows to become available after plow-owning households have finished planting
}

\section{READING THE RAINS}

For Bonam farmers, drought is not a new phenomenon. They can recall several droughts and subsequent famines that occurred in the past, including those of the mid-1970s and mid-1980s. They are usually referred to by the name of places where people went to buy grain or by events associated with them, such as the descent of camels from the northern regions. But they maintain that in recent decades climate has shifted toward lower annual rainfall levels, shortening of the rainy season, and greater frequency of dry periods during the season (Roncoli et al. 1999). The 1997 rainy season exhibited all these characteristics, and several elders who were interviewed emphasized that it was one of the worst years they had ever seen

Farmers' accounts largely converge with the actual meteorological data as they stressed the failure of planting rains as the main problem (Fig. 3). Despite a few scattered showers in May and early June, there were no planting rains (sigri saaga) during June and first half of July. ${ }^{6}$ A few such rains fell in late July, enabling farmers to begin sowing their fields, but by then it was getting too late to sow sorghum and millet, the main staple crops. As early August approached, which is generally recognized as the limit to viable planting, farmers resorted to sowing after no more than a drizzle or even at the mere sight of clouds, hoping for rain. But left in dry soil, much of the seed was

\footnotetext{
${ }^{6}$ Sigri saaga rains are rains that fall in the early part of the rainy season and deposit at least $20 \mathrm{~mm}$ of rain (Roncoli et al. 2000b)
} 
eaten by birds and insects. Because crops repeatedly failed to become established, farmers had to replant their fields as many as 8 times, sometimes replanting with shorter duration varieties as the season progressed. A farmer lamented that it was as if the seed had been cooked; another declared that is was as if a cruel joke were being played at their expense. Several said that, had they known that the season was going to be this bad, they would have not bothered to keep planting but would have migrated to Côte d'Ivoire with their families.

The rains continued in very aberrant ways, fulfilling farmers' premonitions. August, which is normally the wettest month, was again relatively dry. But September brought torrential rain that farmers recall damaging crops and flooding valley bottom fields they had planted as a measure against the drought. According to farmers, premature end of the rains compounded the other problems, resulting in the failure of most crops, especially those planted late. ${ }^{7}$ Among staple grain crops, sorghum suffered more than millet, which is more resistant to water deficit, but millet was also damaged by pests during grain filling.

In retrospect, farmers recalled numerous hints and signs that had announced an unfavorable season. For instance, rains began in the north rather than in the south, as is normal. Temperatures during the previous dry season were milder than usual in the early part and cooler than usual in the later part of the season. Violent winds and persistent fog also announced perturbations. Another commonly relied upon forecast indicator, the flower and fruit production of certain local trees, was also poor, giving reasons for apprehension. ${ }^{8}$ But most of all, the nature of rainfall at the onset of the season, and especially whether it conforms to or diverges from an idealized pattern, and the number of plantings required to establish crops are considered the most trustworthy predictors of crop performance (Roncoli et al. 2000). By the end of planting time it was obvious to farmers that the harvest would be very poor even in the best of circumstances. In other words, farmers knew that a crisis loomed several months before the harvest and half a year before they began adopting survival strategies that are usually consid-

\footnotetext{
${ }^{7}$ Farmers' accounts diverge from meteorological data obtained in Boulsa that shows rains in early November. They might have been referring to the lack of significant rain in the second half of October, a time when late planted crops needed rain to mature, as having the same effect as the end of the rains. But it could also be due to the spatial variability of late rains

${ }^{8}$ The most common are the karité (French) or taanga (Moré) and the raisinier (French) or sibga (Moré). The respective scientific names are Butyrospermum parkii and Anogeissus leiocarpus
}

ered famine signals, such as eating wild fruits and skipping meals.

No advance warning had been available before the rainy season, since in 1997 the Meteorological Service still deemed scientific forecasts to be too experimental. The irregularity of rainfall was noted by the Famine Early Warning System (FEWS) and a shortfall in production deficit was predicted. ${ }^{9}$ But the severity of the situation was recognized only gradually. By October, FEWS observers noted poor crop conditions, especially in Namentenga and the rest of the Central Plateau. In November, one-third of the grain crop was estimated to be lost in the central, northwestern and northern provinces. Eastern provinces, which are not drought prone, were affected as well. In early December the President appealed to the international community for food aid. It was not until March, when the government updated production figures, that the situation was assessed to be far more severe than expected. It was estimated that crop losses would reach $75 \%$ in some areas of the Samantenga, Séno and Bam provinces, but Namentenga was also mentioned among those suffering from food and water shortages.

From March onward, FEWS bulletins describe the situation as very serious, indicating that households were resorting to consuming famine foods and to migrating elsewhere. They also noted that price increases were placing grain outside of the purchasing power of populations of affected areas, especially lower income households. Prices had been increasing early in the year, but initially did so gradually. This was because more of the grain produced in the southwest was marketed domestically, and the government and NGOs made grain available at subsidized prices through cereal banks. Limited supplies of seed were also distributed. But by April and May, when most households had exhausted their stocks, prices were $50 \%$ above May prices in 1996 and 1997. They would have increased much further if government and NGOs had not again intervened, releasing grain at 140 Communauté Financière Africaine franc (CFA Fr) $\mathrm{kg}^{-1} \cdot{ }^{10}$ Some food aid also reached Bonam through NGOs, the Catholic mission and government programs, but it was far from sufficient to fill the need. By August 1998, Bonam households were paying up to $240 \mathrm{CFA} \mathrm{Fr} \mathrm{kg}{ }^{-1}{ }^{11}$

\footnotetext{
${ }^{9}$ FEWS is a USAID funded program. Monthly bulletins can be found at http://www.fews.org/fewspub.html

${ }^{10}$ The CFA franc was valued at 692 CFA Fr $=1$ US\$ in 1998

${ }^{11}$ The highest price recorded in the FEWS bulletin was 171 CFA Fr kg ${ }^{-1}$. Price monitoring is complicated by the fact that sellers in local markets shift units of measure according to supply. At times of plenty, they use a bowl that will hold $2.75 \mathrm{~kg}$ of sorghum or millet; when grain is scarce they use a smaller one, containing $2.5 \mathrm{~kg}$. But prices are generally cited and recorded 'by the bowl' (assiette)
} 
Table 2. Grain production by 21 households (hh) in the Central Plateau, Burkina Faso (1997 and 1998)

\begin{tabular}{|lcc|}
\hline & Higher rank & Lower rank \\
\hline $\mathbf{1 9 9 7}$ & & \\
Number of producers & 6.5 & 4.8 \\
Number of consumers & 8.8 & 6.1 \\
Grain production & & \\
kg hh $^{-1}$ & 386.60 & 342.80 \\
kg producer $^{-1}$ & 59.48 & 71.42 \\
kg consumer $^{-1}$ & 43.93 & 56.20 \\
$\mathbf{1 9 9 8}$ & & \\
Number of producers & 4.9 & 4.5 \\
Number of consumers & 7.1 & 5.8 \\
Grain production $^{\text {kg hh }}{ }^{-1}$ & & \\
kg producer $^{-1}$ & 2015.40 & 1329.40 \\
kg consumer $^{-1}$ & 411.31 & 295.42 \\
& 283.86 & 229.21 \\
\hline
\end{tabular}

\section{STRATEGIES FOR SURVIVAL}

Soon after the harvest, having fully realized the severity of the situation, families began discussing, negotiating and adopting coping strategies. In some cases the household head gathered all adults in the household to exhort them to be thrifty in using the available grain and to do their best to obtain additional money or food. Those who had relatives employed in towns or farming in Côte d'Ivoire sent word that help would be needed. Production of staple grains (sorghum, millet and maize) had been only a fraction of that in normal years (Table 2). With annual grain requirements estimated at $200 \mathrm{~kg}$ per adult and $67 \mathrm{~kg}$ per child or elderly person (Carter 1997), average household production was barely one-quarter of the per capita demand. ${ }^{12}$ Notably, higher ranking households did not produce more per capita than lower ranking ones. This result partly reflects the larger size and dependency ratio of higher ranking households because they included greater numbers of wives and children. It might also be due to their greater reliance on cash crops and non-farm income. ${ }^{13}$ But cash crops, such as peanut, cowpea, rice and sesame, also failed. A wealthy farmer complained of having lost investments of 20000 CFA Fr for cowpea seed and 30000 CFA Fr for peanut seed because of the drought.

\footnotetext{
${ }^{12}$ Adult men and women count as 1 'consumer', children and elderly count as one-third

${ }^{13}$ The proportions of farmers from higher ranking and lower ranking households who planted these crops were similar but wealthier farmers tend to plant larger areas for market purposes, while resource-limited farmers plant small plots for home consumption. Because farmers do not estimate cultivated areas and often reported total loss of yields, we cannot verify this hypothesis
}

Higher ranking households, however, compensated for the production shortfall by buying more grain throughout the year. Even though they also had to manage their resources carefully and reduce household size by sending sons to Côte d'Ivoire, between what they produced and what they bought, they were able to meet consumption requirements (Table 3). On the other hand, in lower ranking households production and purchases satisfied only $82 \%$ of their consumption requirements. Household food supply was probably supplemented by small purchases by women, transfers from relatives and food aid, which are difficult to document.

Regardless of wealth status, most households tried to minimize grain purchases in July and August, when prices are the highest. This is not only because of seasonal increase but also because at this time money is very scarce and households tend to buy by the bowl rather than by the bag, which affords a better value. Many saved their own grain stocks to be consumed during the farming season, especially during periods of high labor demand. Higher ranking bought one-third and lower ranking households one-fourth of all grain purchased during the year shortly after the harvest and the remainder shortly before the onset of the next farming season. There was no substantial difference in

Table 3. Grain purchases by 21 households (hh) in the Central Plateau, Burkina Faso (1998 and 1999). CFA Fr: Communauté Financière Africaine francs

\begin{tabular}{|c|c|c|}
\hline Households & $\begin{array}{r}\text { Higher rank } \\
8\end{array}$ & $\begin{array}{r}\text { Lower rank } \\
13\end{array}$ \\
\hline \multicolumn{3}{|l|}{ Jan 1998} \\
\hline Consumers $\mathrm{hh}^{-1}$ & 8.8 & 6.1 \\
\hline Expenditures (CFA Fr $\mathrm{hh}^{-1}$ ) & 57237.50 & 21173.08 \\
\hline \multicolumn{3}{|l|}{ Grain purchased } \\
\hline $\mathrm{kg} \mathrm{hh}^{-1}$ & 390.00 & 166.15 \\
\hline $\mathrm{kg}$ consumer $^{-1}$ & 44 & 27 \\
\hline \multicolumn{3}{|l|}{ Jul 1998} \\
\hline Consumers $\mathrm{hh}^{-1}$ & 7.1 & 5.8 \\
\hline Expenditures (CFA Fr $\mathrm{hh}^{-1}$ ) & 82950.00 & 51369.23 \\
\hline \multicolumn{3}{|l|}{ Grain purchased } \\
\hline $\mathrm{kg} \mathrm{hh}^{-1}$ & 514.38 & 305.77 \\
\hline $\mathrm{kg}$ consumer ${ }^{-1}$ & 72 & 53 \\
\hline \multicolumn{3}{|l|}{ Jan 1999} \\
\hline Consumers/hh & 7.9 & 6.1 \\
\hline Expenditures (CFA Fr $\mathrm{hh}^{-1}$ ) & 53268.75 & 24111.54 \\
\hline \multicolumn{3}{|l|}{ Grain purchased } \\
\hline $\mathrm{kg} \mathrm{hh}^{-1}$ & 316.50 & 116.15 \\
\hline $\mathrm{kg}$ consumer ${ }^{-1}$ & 40 & 19 \\
\hline \multicolumn{3}{|l|}{ Total year } \\
\hline Expenditures (CFA Fr hh-1) & 193456 & 98961.54 \\
\hline \multicolumn{3}{|l|}{ Grain purchased } \\
\hline $\mathrm{kg} \mathrm{hh}^{-1}$ & 1221 & 658.08 \\
\hline kg consumer ${ }^{-1}$ & 157 & 110 \\
\hline CFA Fr kg ${ }^{-1}$ & 158 & 150 \\
\hline
\end{tabular}




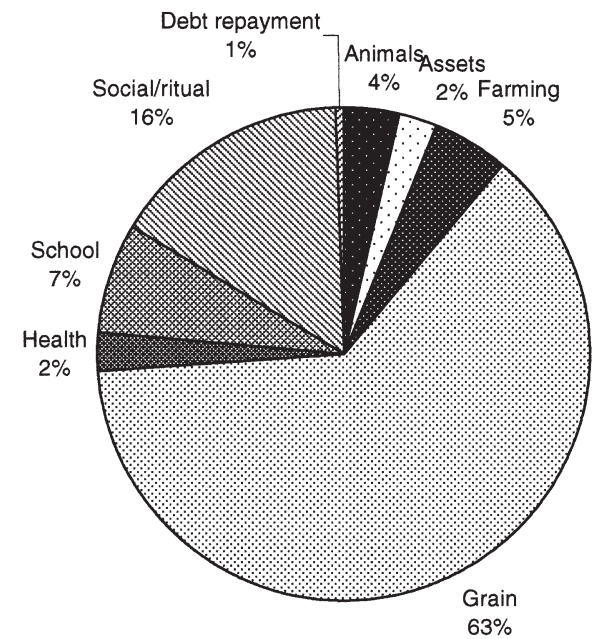

Fig. 4. Expenditures by lower ranking households

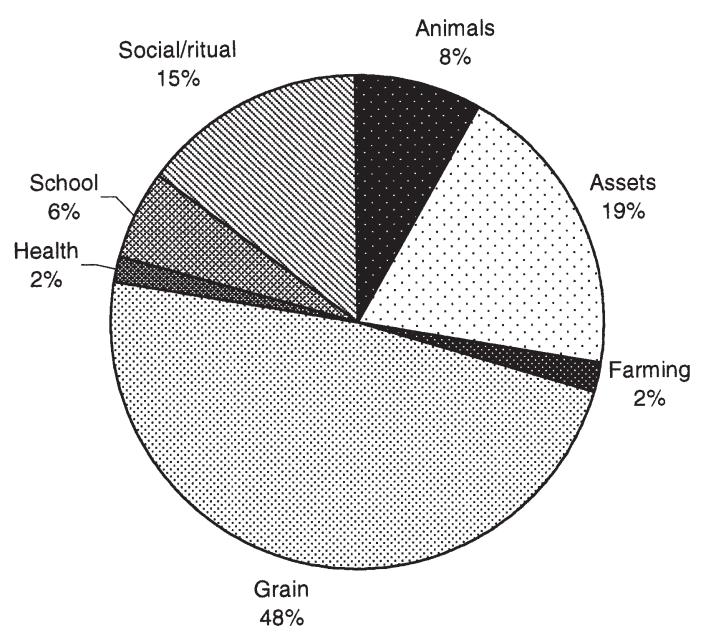

Fig. 5. Expenditures by higher ranking households

grain prices paid by higher and lower ranking households. But grain purchases absorbed a much greater share $(63 \%)$ of the total budget of lower ranking households, limiting their ability to meet other needs or to invest in inputs or assets (Fig. 4). Higher ranking households spent almost half of their total budget on grain but were able to buy livestock and assets as well (Fig. 5).

Soon after the harvest, household heads began to control grain allocation and utilization to ensure that the meager supplies they produced or purchased lasted as long as possible. Food management strategies entailed a combination of control, conflict, compliance and cooperation among men and women, young and old within the household (McMillan 1986, Kevane 2000, Thorsen 2000). These strategies were as follows: (1) reducing the number of consumers by sending young men into migration and children to stay with rel- atives; (2) reducing the number of women cooking and charging 1 woman to cook a common meal rather than allowing each woman to cook separately; (3) supervising women more strictly in how they handle grain for cooking; (4) using a smaller container to measure grain or extending the time between grain allocations to

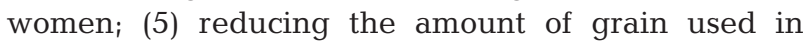
preparing daily meals, i.e., cooking just enough with no provision for leftovers; (6) reducing the number of meals served, by eliminating the morning or midday meal $_{i}(7)$ relying on women's contributions of grain from their own fields or bought with their own money; and (8) consuming bean, cowpea or peanut when available, or famine foods, especially at the peak of hunger during the last $2 \mathrm{wk}$ before the new maize harvest. ${ }^{14}$ There was considerable variation in the adoption and combination of strategies, but some regularity in sequencing. For instance, households lessened the numbers of consumers or of cooks before reducing the daily ration, and cooked less before eliminating meals or eating famine foods.

In addition to the 4 households in our original sample who went to Côte d'Ivoire, $18 \%$ of men, $8 \%$ of women and $15 \%$ children in the remaining households left Bonam between January and June 1998. It was only after the 1998 harvest that households began reconstituting their numbers (Table 3 ). Migration as a way to reduce need was particularly important for wealthier households because they were also larger. Poorer households may be less able to spare members from performing tasks and duties that need to be taken care of in the dry season. High travel costs and increasing ethnic tension and harassment against Burkinabé migrants in Côte d'Ivoire can also be a deterrent. Yet gifts by migrant relatives contributed significantly to grain purchases by lower ranking households, accounting for $27 \%$ of what they spent (Fig. 6). Higher ranking households also derived income from migration but not all was spent on grain (Fig. 7). For instance, a wealthy farmer received $100000 \mathrm{CFA} \mathrm{Fr}$, which he invested in cattle. Another received 650000 CFA Fr, which he used to buy a moped.

Earnings of migrant workers became available only after December and January, when crops are harvested and marketed in Côte d'Ivoire. Most migrants return at the end of the dry season, when grain prices are higher. To take advantage of the lower grain prices

\footnotetext{
${ }^{14}$ Most famine foods are prepared by cooking the young leaves of bushes or trees that become available in May and June. Among the most common are pimpirga, lelongo, kalyanga, hadga, kalquempoodo, katempongo, konkuega, keglega, pelga kilogo and kesega. Wild leaves that grow around the compound and animal pens (sugda, kienba, zinba and vampoonse) are also used
} 
shortly after the harvest in Burkina Faso and the higher demand for meat to be consumed at harvest festivities and Christian holidays, most households began selling livestock early in the year. By January 1998, 56\% of households had sold goats, $36 \%$ had sold sheep and $32 \%$ had sold cattle. By June 1998, $39 \%$ of small ruminants and $38 \%$ of cattle had been sold. ${ }^{15}$ While small livestock is routinely sold when cash is needed, cattle sales confer a much higher degree of stress because low prices due to distress sales and poor animal health may mean that households are unable to reconstitute their stock after the crisis (Fafchamps et al. 1998). Of the households that owned cattle in January 1998, most had sold 1 or more head by June. Some of the goats and sheep that were sold belonged to women; in some cases they were volunteered by the owner to help the family, and in others they were seized and sold by the household head. But few men or women provided explicit information about them because relying on women's property to feed the household is considered to reflect poorly on the household head.

Both higher and lower ranking households sold livestock, but the wealthy ones had more animals to sell and earned a lot more. In their case, livestock sales accounted for twice as large a proportion of the food budget as in poor households (Figs 6 \& 7). Rich farmers with trading income both bought and sold animals as part of their herd management, taking advantage of low prices to buy younger animals to raise. During the year, for instance, a farmer-trader sold 12 bullocks and 9 cows and bought 7 younger bullocks. As the dry season progressed, animal prices began falling to a record low because of distress sales and poor health status caused by lack of grass and water. One farmer complained that 'goats were selling at the price of chickens.' Low livestock prices created a windfall for traders from urban markets and neighboring countries who operate in the Puytenga market. They were able to buy emaciated animals, fatten them and then resell them at great profit.

Trading and other non-farm income sources played key roles in helping households meet their needs, regardless of wealth status. Consistent with data from other research conducted in Burkina Faso (Delgado 1989), about one-quarter of all money spent on food was derived from such activities. Trading and skilled work, such as tailoring, were among the most remunerative as well as prestigious. Men from the blacksmith caste do iron work, which can also be quite profitable (1 higher ranking household was among them), and their wives make and sell pottery. A wealthy

\footnotetext{
${ }^{15} 56 \%$ of the farmers had sold goats, $36 \%$ sold sheep and $32 \%$ sold cattle
}

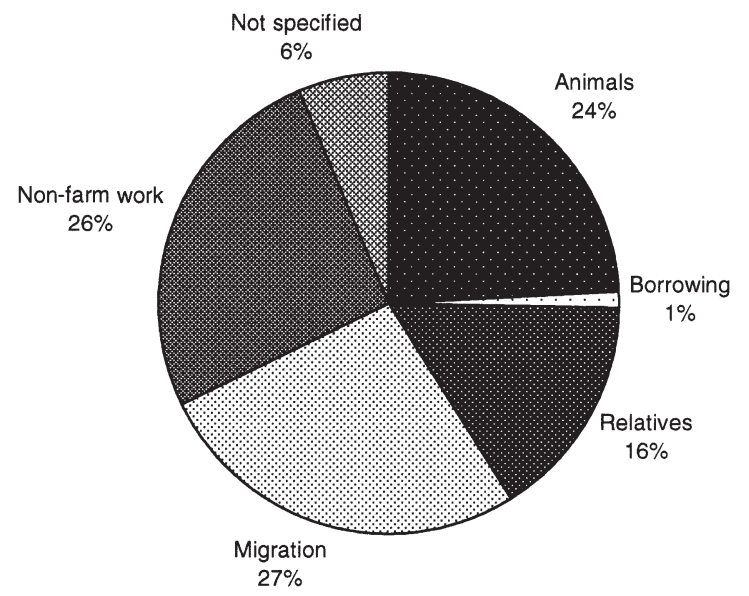

Fig. 6. Cash sources for grain purchases, lower ranking households

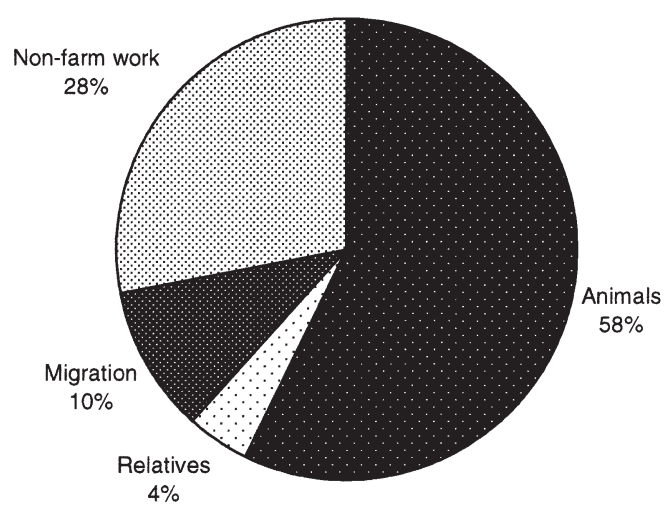

Fig. 7. Cash sources for grain purchases, higher ranking households

household sent sons to do gold panning in a mining area and another received income from a son who was employed in the construction of the rice perimeter. A few lower ranking ones derived revenues from butchery and the sale of firewood, and a few others practiced divination and traditional medicine, among whom 1 man earned about 20000 CFA Fr by capitalizing on the area's reputation in Ouagadougou for witchcraft.

However, food shortage made most local trading and non-farm activities less profitable because people had less money to invest in them and to buy their products. The high price of agricultural commodities and scarcity of water greatly reduced women's earnings from traditional dry season activities such as food processing and beer brewing. Even village grain traders were not benefiting from high grain prices. Because they gain from small price increments on a high turnover of grain bought and sold, in a situation where nobody had grain to sell or money to buy it, they were losing business and profits. 
Kin also helped households, especially lower ranking ones, to buy grain (Figs $6 \& 7$ ). This was particularly the case for 1 household related to the chief and a few others who had relatives employed in town. Some women went to visit their paternal kin or married daughters in less affected areas and came back with food. The key role of kinship as a moral framework that validates appeals for assistance at times of crisis is reflected in household livelihood decisions. Despite food insecurity, both higher and lower ranking households did not fail to invest in building and consolidating kinship networks and social relationships through marriage transactions, baptism receptions and funeral ceremonies (Figs 4 \& 5). Three of the higher ranking households and 1 among lower ranking ones were able to take new wives despite the shortage of food and money. Marriage not only increases household labor but also expands affinity ties on which to draw in time of need. Funeral celebrations, which occur during the dry season and require hosting and feeding hundreds of guests for $3 \mathrm{~d}$ are especially salient institutional venues in which lineage identity is affirmed and with it the social claims to land, labor and resources it mediates (Berry 1989).

When all other resources and strategies were exhausted, a few poor households also resorted to borrowing, pawning or mortgaging crops. This meant that they had to repay loans by selling crops shortly after harvest, when prices are lowest. Therefore, they were less able to take advantage of the good yields obtained in 1998 to recover from distress sales during the year. Women borrowed from their own relatives or from other petty traders or beer brewers, or secured loans on behalf of their households. It is believed that women are more successful at borrowing because lenders are moved to pity for a mother and her children and because the women are considered more likely to repay the loan, being thriftier, more easily intimidated or less able to run away in case of default. The perception of women as more financially responsible extended to their husbands. One man entrusted his wife with money he intended to save to buy food during the farming season. Another deposited with his wife half of what he earned as a sort of savings account to be able to accumulate enough for emergencies or investments.

Women also sold cloth, utensils and jewelry they had accumulated for their daughters' weddings to traders from Puytenga market who toured the countryside in search of profitable deals, knowing that people were desperate for money. Many stories circulated in Bonam and surrounding areas about rural women providing sexual services to Boulsa or Puytenga traders in exchange for food, but obviously, they could not be directly verified. Rather than condemnation, they generally evoked words of commiseration and commentaries on mothers' self-denying dedication to their children's well-being. Informal interviews with women suggest that women's key roles in ensuring household livelihood has increased bargaining power vis-à-vis their husbands. Women are more often consulted in case of crop or livestock sales or major household purchases. Wives whose relatives help at times of need may be able to visit them more often or stay longer. Petty traders whose earnings help buy food for the household may be able to take more time off farm work to go the market. Husbands also increasingly involve wives in farming decisions, such as whether to make a new field and what proportion of each crop to plant. Although marriage transactions are still negotiated by men, women may derail a marriage they disapprove of by protesting that they had to sell the items they are responsible to provide to their marrying daughters. These shifts in gender relationships seems to be more common for older women who have produced children to adulthood than for younger wives. They also tend to occur more often in poorer monogamous households than among wealthier polygynous ones. This may be due to their being less dependent on women's contributions as well as to the greater influence of Islam, especially among households involved in trade.

\section{AGRICULTURAL ADJUSTMENTS}

The fact that most households entered the farming season with a depleted financial base and labor force had serious implications for their ability to manage risks and resources effectively. As usual, farmers strove to minimize cash investments in agriculture, but in some cases they were unable to do so because many had consumed all their seed before planting. The percentage of farmers who purchased seed almost doubled from $43 \%$ in 1997 to $76 \%$ (62.5\% of higher ranking and $85 \%$ of lower ranking households) in 1998. In the case of staple grains, this was a deviation from the common practice of carefully selecting and storing seed from season to season. Most of those who bought seed obtained it from fellow farmers, but some resorted to planting grain they had bought in the market for consumption. Planting seed purchased in the market is risky because one does not know from where it comes, for how long and in what conditions it has been stored, or even the variety. A bag of sorghum may contain different varieties that traders have bought on various markets. Several Bonam farmers unknowingly planted a sorghum variety that had come from the much wetter southwestern part of the country and that was maladapted to the shorter rainy season of the Central Plateau. Consequently their yields would have been poor even if the 1998 rains had been good. 
The 1997 drought stimulated interest in short duration improved sorghum varieties, although none were available locally. But short and medium duration varieties have been imported from the drier northern provinces through spontaneous farmer-tofarmer exchange. Women are instrumental in the diffusion of new varieties that they may come across while helping other women cook, attending markets or funerals, or visiting relatives in other areas. Medium duration (70 to $90 \mathrm{~d}$ ) varieties, such as piswopoi, kurbulli, fibmiugu and yadega, have largely replaced longer duration (120 to $150 \mathrm{~d}$ ) varieties that were grown in the past, such as belko, gambré and balinga. But this shift entails costs and risks because longer duration varieties, when planted early and able to develop fully, are more productive, less vulnerable to weeds, pests and water stresses, more durable when stored, and considered more palatable and nutritious. A 50 d variety known as pisnu (which means 50 in Moré) is also planted in small manured plots together with or shortly after maize, but it requires higher soil fertility and more careful weeding than other varieties. These requirements limit widespread adoption, but most farmers also dislike its poor taste and cooking properties, and their wives resent the fact that it makes such a poor dish that it embarrasses even the best cooks. ${ }^{16}$

The desire to shorten the hunger season led farmers to increase maize planting because maize matures several weeks before staple grains. Households growing maize doubled from $33 \%$ in 1997 to $76 \%$ of (higher ranking and lower ranking) households in 1998, and some of those who did farm maize in 1997 expanded their fields. Hunger even pushed many households to risk planting maize 2 or 3 wk earlier than they normally would. Because of maize's vulnerability to water deficit, farmers usually wait to plant it after a 10 to $12 \mathrm{~d}$ dry period that usually occurs between mid-June and early July, coinciding with the visible phase of the 8th lunar cycle of the year. But unexpectedly in 1998 this dry period stretched into a full month, with no rainfall between 8 June and 12 July, so that all the maize that had been planted before wilted and died. Once it began raining again in mid-July, it did so heavily, trig-

\footnotetext{
${ }^{16}$ The advantage offered by pisnu's shorter duration stimulated farmer experimentation. In a nearby village, farmers selected a $50 \mathrm{~d}$ variety with better taste and texture that was obtained by the extended household of Islamic clerics who inhabit the village from their former Koranic teacher in the northern town of Kaya. Availability of labor from over 100 Koranic students residing and studying with them enabled them to plant the more labor-intensive pisnu on most of their lands. Consequently their village was spared from the hunger that plagued the surrounding area following the 1997 drought
}

gering such a proliferation of weeds that farmers could barely keep up removing them and had no time to replant maize.

The inability to either save or buy seed also meant that few farmers were able to grow peanut, a common cash crop and cooking ingredient as well as an important stage in crop rotation to restore soil fertility. Only 4 (19\%) households, 2 higher ranking and 2 lower ranking ones, planted peanut in 1998, compared with $43 \%$ the year before. Some were unable to plant peanut because they lacked seed or cash to buy it, while others were constrained by lack of labor. Those few who had means to invest in peanut farming benefited from the price increase that resulted from shortage in local supply. A farmer-trader invested 60000 CFA Fr in seed and 43500 CFA Fr in labor, and borrowed a tractor from a relative to prepare his land at no cost. The favorable rains of 1998 resulted in good yields, and he harvested a total of $6400 \mathrm{~kg}$ for a net profit of 643200 CFA Fr at harvest prices. In practice his net profit may have been greater because he had not sold all the grain immediately after harvest and the price of peanut was likely to increase during the year.

Among farmers interviewed, some expanded and others reduced their land holdings in 1998. Expansion was mostly in lowland fields, and sometimes more elevated fields that had performed poorly in 1997 were abandoned because of the drought. Increasing exploitation of valley bottom fields has been one of the main ways in which farmers have responded to drought in recent years. Competition for these lands has increased to such an extent that farmers declared that they would continue farming valley bottom fields even if abundant rainfall was expected because uncultivated land may be occupied by distant relatives who may be impossible to dislodge. The risk of flood damage to crops during an occasional wet season was deemed preferable to the loss of an invaluable resource that insures them against the much more frequent occurrence of drought. Land tenure is still defined by kin group affiliation, and some lower ranking households controlled the best valley land, having settled in an area on the margin of the village that in the past was less desirable because of dense vegetation and wild animals. But the ability to put land into cultivation is predicated upon labor, plows and other resources, so some households were unable to farm all of the land at their disposal. Prosperous, prominent farmers, on the other hand, could use their influence in the community and their ability to assist with loans or plow services to borrow land from others. The farmertrader's peanut field mentioned above was developed on borrowed land.

Loss of labor to migration was one of the main constraints stated by farmers as a reason for having re- 
duced their cultivated area in 1998, in addition to loss of land to the reservoir and soil hardening. Nutritional stress added to migration in depleting household labor forces. In some cases, people were too weak from hunger to be able to work for more than a few hours each day. Lack of food and money also made it difficult to mobilize extra-household labor by way of labor parties. While $33 \%$ of households had engaged labor parties during the 1997 season, in 1998 only 3 (14\%) were able to do so. This meant that family members, including women, had to work harder in the household fields, and had less time and energy to develop personal fields. Women reported that the increasing importance of women's work in the production of household grain is resulting in their greater involvement in decisions about surplus sales.

Labor constraints hindered the implementation of soil and water conservation practices such as straw mulching, stone barriers, grass hedges and $z^{17} i^{17}$. While farmers recognize these measures to be effective in mitigating climatic risk and in improving yields, they are also very labor intensive, requiring up to $200 \mathrm{~h}$ ha $^{-1}$ (Sanders et al. 1990). Their feasibility was also limited by soil hardening and by shortage of straw caused by the previous year's drought, and by the creation of the reservoir and irrigated perimeter, which took over an area where animals used to graze and people cut grass for mulch. But 2 higher ranking households were able to organize communal labor parties to transport and spread straw in his fields, and the farmer-trader mobilized people to dig zai holes and build stone barriers in exchange for grain.

Production in 1998 was generally satisfactory and met household consumption requirements (Table 2). Significantly, unlike in the previous year, per capita production by higher ranking households was greater than for lower ranking ones. This difference may have been due to the risks and trade-offs lower ranking households were forced to engage in as a result of food insecurity, as well as a reflection of greater priority on food production prompted by the experience of a year of hunger and high grain prices. Because of their larger size and greater social obligations, higher ranking households were eager to ensure their food self-sufficiency. This emphasis may have been reflected in closer attention and greater intensity of labor deployed on staple grain fields rather than on expansion of cultivated area or cash investments, which remained relatively low in all cases. ${ }^{18}$

Among all sample households, only 1 ended the year following the 1997 harvest failure having gained rather than lost wealth. A farmer-trader included as a separate case study also had a positive balance. Both households in question benefited from non-farm income from skilled work and trade as well as from transfers from migrant sons and urban-based relatives. Despite having to buy large quantities of high price grain, they were able to invest in cattle, buy a moped and marry a new wife each. One sent children to attend high school in the capital city, and the other made a $40 \mathrm{~d}$ pilgrimage to Mecca that enhanced his prestige in the local Muslim community. Both stated their intention to invest surplus income from the good 1998 harvest into trading of non agricultural items as a low-risk intermediate venture between livelihood needs and livestock investments.

\section{CONCLUSION}

Counteracting the view of African rural communities as inherently vulnerable, the ability of livelihood systems to cope with or recover from climate shocks has been cited as evidence of the rationality and resilience of rural livelihoods (Torry 1984, Mortimer 1989). But an appreciation of the resourcefulness of African farmers should not overlook the possibility that coping may entail painful trade-offs, additional risks and unequally distributed costs, as the case presented here illustrates. Furthermore, it should not be taken as a reason for neglecting crisis prevention or preparedness or for disengaging from development commitments (Gray \& Kevane 1993), but as a resource to draw upon.

Farmers' observations of climatic and agronomic interactions during planting time can help predict harvest failure and food insecurity long before their occurrence, as they did in 1997, and with sufficient advance notice to plan needed interventions. They should be incorporated into seasonal rainfall forecasting and famine early systems, but more micro-level research and closer integration of meteorological, agricultural and social sciences are called for to understand better how information can be disseminated and applied. The diversity of users' needs and the disparity of the means at their disposal must be taken into account to devise relevant and realistic applications (Ingram et al. 2002).

For farmers to be able to respond optimally to a forecasted climate shock as well as for families to withstand its consequences, they need more than information. It is necessary to integrate science and de-

\footnotetext{
${ }^{17} Z$ ai (meaning 'scratching') is a fertility restoration and water conservation technique that has been adopted from the drier northern provinces and promoted by extension and NGOs since the early 1990s. Seed is planted in holes (20 to $40 \mathrm{~cm}$ apart) filled with organic matter, with the dug earth amassed downhill in the form of a half-moon barrier to retain rainwater

${ }^{18}$ Higher ranking households invested an average of 9375 CFA Fr compared with 7810 CFA Fr spent by lower ranking households
} 
velopment interventions in ways that help improve the livelihood options and the productive capacity of farming households, especially those with limited resources. An appreciation of the centrality of the women's work and income for household food security should also guide these efforts beyond a householdfocused approach toward one that considers differential vulnerabilities and entitlements.

The research in Bonam suggests that access to laborsaving technologies that accelerate land preparation and planting, such as plows, and timely availability of locally adapted seed varieties of food and cash crops are key elements of agricultural adaptation to climate variability. At the same time, access to credit that is not tied to specific crops or inputs and improved market access can increase the flexibility of farmers' responses and facilitate livelihood diversification. But, because human labor remains such a key element in local production systems, donors, government and the private sector should also be working together to ensure that affordable grain is available to rural families at times of food insecurity, such as that which followed the 1997 drought.

Acknowledgements. Support for this research was provided by the Office of Global Program of the US National Oceanic and Atmospheric Administration. We acknowledge the invaluable collaboration of our institutional partners in Burkina Faso, Plan International, especially Country Representative Felipé Sanchez and Agricultural Program Manager Eric Mamboué, and the National Meteorological Service, especially Director Dr. Frédéric Ouattara. We also thank Ian Flitcroft, Christine Jost and Gerrit Hogenboom for help at different stages of the research.

\section{LITERATURE CITED}

Adams AM, Cekan J, Sauerborn R (1998) Towards a conceptual framework of household coping: reflections from rural West Africa. Africa 68:263-283

Benson C (1998) Drought and the Zimbabwe economy, 1980-93. In: O'Neill H, Toye J (eds) A world without famine? New approaches to aid and development. Macmillan, Houndsmills, p 241-273

Berry S (1989) Social institutions and access to resources. Africa 59:41-55

Blaikie P, Cannon T, Davis I, Wisner B (1994) At risk: natural hazards, people's vulnerability, and disasters. Routledge, London

Bratton M (1987) Drought, food and the social organization of small farmers in Zimbabwe. In: Glantz M (ed) Drought and hunger in Africa: denying famine a future. Cambridge University Press, Cambridge, p 214-244

Brock K (1999) Implementing a sustainable livelihoods framework for policy-directed research: reflections from practice in Mali. Institute for Development Studies, Working Paper no. 90. University of Sussex, Brighton

Campbell DJ (1990) Strategies for coping with severe food deficits in rural Africa: a review of the literature. Food Foodways 4:143-162
Carter M (1997) Environment, technology, and the social articulation of risk in West African agriculture. Econ Dev Cult Change 45:557-590

Corbett J (1988) Famine and household coping strategies. World Dev 16(9):1099-1112

Cutler P (1984) Famine forecasting: prices and peasant behavior in Northern Ethiopia. Disasters 10:181-188

Davis S (1993) Are coping strategies a cop-out? IDS Bull 24: $60-72$

Davis S (1996) Adaptable livelihoods: coping with food insecurity in the Malian Sahel. Macmillan, London

Delgado CL (1989) The changing economic context of mixed farming in savanna West Africa: a conceptual framework applied to Burkina Faso. Q J Int Agric 28:3-4

Dercon S (1996) Risk, crop choice, and savings: evidence from Tanzania. Econ Dev Cult Change 44:485-513

Devereux S (1993) Goats before ploughs: dilemmas of household response sequencing during food shortages. IDS Bull 24:52

Downing $\mathrm{T}$ (1990) Monitoring and responding to famine: lessons from the 1984-85 food crisis in Kenya. Disasters $14: 204-229$

Ellis F (1998) Household strategies and rural livelihood diversification. J Dev Stud 35:1-38

Fafchamps M, Udry C, Czukas K (1998) Drought and saving in West Africa: are livestock a buffer stock? J Dev Econ 55: 273-305

Gray L, Kevane M (1993) For whom is the rural economy resilient? Initial effects of drought in Western Sudan. Dev Change 24:159-176

Hansen TS, Reenberg A (1998) Approaching local limits to field expansion - land use pattern dynamics in semi-arid Burkina Faso. Dan J Geogr 98:56-70

Hussein K, Nelson J (1998) Sustainable livelihoods and livelihoods diversification. Institute for Development Studies Working Paper no. 69. University of Sussex, Brighton

Ingram K, Roncoli C, Kirshen P (2002) Opportunities and constraints for farmers of West Africa to use seasonal precipitation forecasts with Burkina Faso as a case study. Agric Syst (in press)

Jiggins J (1986) Women and seasonality: coping with crisis and calamity. IDS Bull 17:9-18

Kevane M (2000) Extrahousehold norms and intrahousehold bargaining: gender in Sudan and Burkina Faso. In: Spring A (ed) Women farmers and commercial ventures. Lynne Rienner, Boulder, p 89-112

Lambert RJ (1994) Monitoring local food security and coping strategies: lessons from information collection and analysis in Mopti, Mali. Disasters 18(4):332-343

McMillan D (1986 ) Distribution of resources and products in Mossi households. In: McMillan D, Hansen A (eds) Food in Sub-Saharan Africa. Lynne Rienner, Boulder, p 260-273

Mortimore M (1989) Adapting to drought: farmers, famines, and desertification in West Africa. Cambridge University Press, New York

Painter T, Sumberg J, Price T (1994) Your terroir and my 'action space': implications of differentiation, mobility, and diversification for the approche terroir in Sahelian West Africa. Africa 64:447-464

PNUD (1997) Rapport sur le dévéloppement humain durable: Burkina Faso. Programme des Nations Unies pour le Dévéloppement, Ouagadougou

Reardon T, Matlon P (1989) Seasonal food insecurity and vulnerability in drought-affected regions of Burkina Faso. In: Sahn D (ed) Seasonal variability in Third World agriculture: the consequences for food security. Johns Hopkins University Press, Baltimore, p 118-136 
Reardon T, Taylor E (1996) Agroclimatic shock, income inequality, and poverty: evidence from Burkina Faso. World Dev 24:901-914

Reardon T, Matlon P, Delgado C (1988) Coping with household-level food insecurity in drought-affected areas of Burkina Faso. World Dev 16:1065-1074

Roncoli C, Bahadio B, Boena S (1999) The role of rainfall information in farmers' decisions: ethnographic research in the Central Plateau (Burkina Faso). Technical Report, Climate Forecasting and Agricultural Resources Project. University of Georgia, Athens

Roncoli C, Ingram K, Kirshen P (2001) Reading the rains: local knowledge and rainfall forecasting among farmers of Burkina Faso. Soc Nat Resour 15 (in press)

Sanders J, Nagy J, Ramaswamy S (1990) Developing new

Submitted: February 14, 2000; Accepted: February 13, 2001 agricultural technologies for the Sahelian countries: the Burkina Faso case. Econ Dev Cult Change 39:1-22

Scoones I (1998) Sustainable rural livelihoods: a framework for analysis. Institute for Development Studies Working Paper no. 72. University of Sussex, Brighton

Thorsen D (2000) Dividing or sharing responsibilities? Intrahousehold budgeting among Bissa and Mossi of Burkina Faso. Paper presented at the African Studies Association Annual Meetings, Nashville, 15-19 November 2000

Torry W (1984) Social science research on famine: a critical evaluation. Hum Ecol 12:227-252

Whitehead A (1981) 'I'm hungry, mum': the politics of domestic budgeting. In: Young K, Wolkowitz C, McCullagh R (eds) Of marriage and the market: women's subordination in international perspective. CSE Books, London, p 88-111

Proofs received from author(s): June 22, 2001 